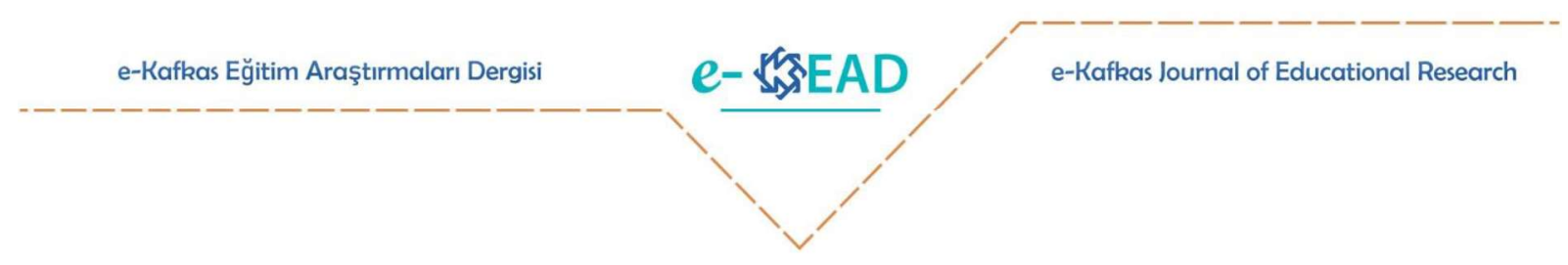

\title{
Okul Öncesi Öğretmen Adaylarının Etkinlik Planlarında Aile Katılımı Boyutunun İncelenmesi* $^{*}$
}

\section{Investigation of Family Involvement Dimension in Preschool Prospective Teachers' Activity Plans*}

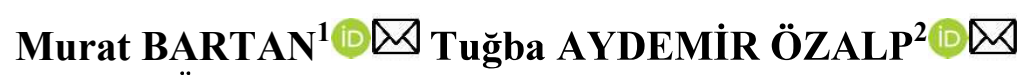

Atıf: Bartan, M. ve Aydemir-Özalp, T. (2019). Okul öncesi öğretmen adaylarının etkinlik planlarında aile katılımı boyutunun incelenmesi. e- Kafkas Eğitim Araştırmaları Dergisi, 6(4), 21-32.

Araştırma Makalesi Geliş Tarihi:08.11.2019 Kabul Tarihi: 27.12.2019

Doi: $10.30900 /$ kafkasegt. 644316

Öz

Araştırmanın amacı, Kütahya Dumlupınar Üniversitesi okul öncesi öğretmenliği programı 4. Sınıf öğrencilerinin öğretmenlik uygulaması dersi kapsamında Milli Eğitim Bakanlığı 2013 Okul Öncesi Eğitim Programı'na uygun olarak hazırladıkları etkinlik planlarındaki aile katılım boyutunun incelenmesidir. Temel nitel araştırma yönteminin kullanıldığı araştırmada veriler 8 gönüllü öğretmen adayının görüşme verileri ve 42 öğretmen adayının 668 etkinlik planları yoluyla toplanmıştır. Veriler tematik analiz ile çözümlenmiştir. Araştırma sonucunda öğretmen adaylarının çoğunluğunun etkinlik planlarında aile katılımı boyutuna yer vermedikleri belirlenmiștir.Bu adaylar, aile katılımına etkinlik planlarında yer vermeme sebepleri olarak kendilerini aile katılımı etkinliği planlama ve uygulama konusunda yetersiz hissetmeleri, okul yönetiminin aileler ile öğretmen adaylarının birebir iletişim kurmasını istememeleri ve öğretim üyesinin aile katılımı çalışması yapmasını istememeleri olarak belirtmişlerdir. Etkinlik planlarında en çok okulda hedeflenen kazanımların pekiştirilmesine yönelik etkinlik önerisinin planlandığ ve aile katılımına en çok bütünleştirilmiş etkinliklerde yer verildiği görülmüştür. Öğretmen adayları öğretmenlik uygulaması süresinin, etkinliği uygulama ve takibini yapma açısından yetersiz olduğunu belirtmişlerdir.

Anahtar kelimeler:Okul öncesi eğitim, aile katılımı, öğretmen adayı, etkinlik planı

\section{Abstract}

The aim of the study is to investigate the family participation dimension of the activity plans prepared by the 4th grade students of Kütahya Dumlupinar University preschool teaching department in accordance with the Ministry of National Education 2013 Preschool Education Program.The data were collected through interview data of 8 prospective teachers and 668 activity plans of 42 prospective teachers. The data were analyzed by thematic analysis. As a result of the research, it was determined that most of the prospective teachers did not include the dimension of family participation in their activity plans. The reasons for not including family participation in the activity plans were that they felt inadequate in planning and implementing family participation activities, that the school administration did not want families and teacher candidates to establish one-to-one communication and that lecturer did not want to participate in family participation studies. In the activity plans, it was seen that the activity proposal aimed at reinforcing the targeted gains in the school was the most and the family participation was mostly included in the integrated activities. Prospective teachers stated that the duration of teaching practice was insufficient in terms of implementation and follow-up of the activity.

Keywords: Early childhood education, family involvement, prospective teacher, activity plan

\footnotetext{
* Bu araştırma 6. Uluslararası Okul Öncesi Eğitimi Kongresinde (IECEC/UOEK-2019) sözlü bildiri olarak sunulmuştur.
} 


\section{Giriş}

Aile katılımı, çocuğun gelişim ve eğitiminin en yüksek düzeyde olabilmesi için okul-aile arasında kurulan karşılıklı işbirliği, iletişim ve etkileşim süreci olarak tanımlanmaktadır (Arabacı, 2018, Epstein, 2002, Tezel Şahin ve Ünver, 2005). Aile katılımı çalışmalarının çocukların bilişsel, dil, sosyal-duygusal, psiko-motor ve fiziksel gelişim gibi tüm gelişim alanlarını ve aynı zamanda akademik başarılarını da desteklediği bilinmektedir (Berns, 2012; Heckman,2011; Keçeli-Kaysılı, 2008). Bu sebeple ailenin eğitim-öğretim sürecine aktif katılması ve okulda verilen eğitimi desteklemesi beklenmektedir. Bu katılımda çocuğun gelişimsel ve eğitimsel hedeflere ulaşması için sadece tek taraflı bilgilendirme süreci değil bir ortaklık söz konusudur. Ortaklık kavramı ile ifade edilmek istenen, eşgüdümlü çalışma, çocuğun öğrenme süreci ve bu sürecin desteklenmesi ile ilgili eşit sorumluluk sahibi olma, sistematik, önleyici ve çözüm odaklı olarak gerçek ve etkin katılımdır (Christenson, 2004). Aile katılımı çalışmaları aile ile iş birliği yapmanın en etkili yollarındandır (MEB,2013). Aynı zamanda kuramsal temelden bakıldığında Bronfenbrenner tarafından geliştirilen ekolojik sistemler kuramı eğitimde ve gelişimde aile katılımının ne denli gerekli ve önemli olduğunu ortaya koymuştur. Ekolojik sistemler kuramına göre çocuğun gelişimini etkileyen dört farklı katman vardır. $\mathrm{Bu}$ katmanların kendi içerisinde ve aralarında kurulan ilişkiler bireyin gelişimi ile davranışlarını şekillendirmektedir (Trawick-Swith, 2013). Dolayısıyla öğretmen ve ailelerin ekolojik bakış açısına sahip olmaları bu sürecin etkin olarak yürütülebilmesinde önemli bir faktör olabilmektedir (Keçeli-Kaysıl1,2008).

2013 Okul öncesi eğitim programında, aileler ile aile eğitimi ve aile katılımı kapsamında çalışmalar yapılmaktadır. Aile katılımı çalışmaları ise, aile iletişim etkinlikleri, ailenin okulda yapılan etkinliklere katılımı, bireysel görüşmeler ve ev ziyaretleri olarak dört başlık altında toplanmıştır. Aile iletişim etkinliklerinde amaç, aile ile okul arasında iletişim kurmak ve bu iletişimin devamlılığını sağlamaktır. Bu kapsamda telefon görüşmeleri, kitapçıklar, bültenler, fotoğraflar, panolar, iletişim defterleri, görsel-işitsel kayıtlar, toplantılar, haber mektupları, okul ziyaretleri, geliş gidiş zamanları, internet temelli uygulamalar, dilek kutuları ve portfolyolar kullanılabilmektedir. Ailenin okulda yapılan etkinliklere katılımı, aile üyelerinin okulda gözlemci olarak bulunmaları, çeşitli materyallerin hazırlanmasında ve onarımında yardımcı olmaları, alan gezileri ve sosyal etkinliklere katılarak öğretmene yardımcı olmaları, sınıfta yeteneğine, mesleğine uygun bir etkinlikte yer almaları, çocuklarla birlikte etkinlik yapmaları yoluyla gerçekleştirilebilmektedir. Burada dikkat edilmesi gereken noktalar; ailelerin yapabilecekleri etkinliklerden başlanması ve aile katılım tercih formu ile aileleri tanıyarak neler yapılabileceğine ilişkin bilgi edinilmesidir. Grupla yapılan toplantıların dışında çocuğun gelişiminin bireysel olarak değerlendirilmesine imkân veren bireysel görüşmeler, çocuğun gelişimi, bireysel sorunları, güçlü ve desteklenmesi gereken yanları ile ilgili aileye bilgi vermek ve çözüm yolu aramak amacıyla yapılmaktadır. Ev ziyaretleri ise, yılda iki kez öğretmenin ailenin evine giderek çocuğu ve aileyi daha iyi tanıması kapsamında önerilmektedir (Çağdaş ve Seçer, 2004, MEB, 2013,Tezel Şahin ve Özyürek, 2010).

Aile katılımı çalışmaları sürecinde öğretmenlere, aile ile işbirliğinin oluşturulması, oluşturulan işbirliğine yönelik uygulamaların yapılması ve bu işbirliğinin sağlıklı iletişim yolu ile korunması konusunda büyük bir görev düşmektedir. Öğretmenlerin bu konuda etkili bir planlama yapmaları ve eğitim programına uygun etkinlikler ile süreçte aktif rol almaları gerekmektedir (Çamlıbel-Çakmak, 2010). Bu bağlamda öğretmenlerin hizmet öncesi dönemde aldıkları aile katılımı ve eğitimi ile iletişim konularındaki derslerin ayrıca öğretmenlik uygulaması dersindeki deneyimlerinin aile ile işbirliği ve iletişimin sağlanması bakımından önemi artmaktadır. Literatür incelendiğinde aile katılımı ile ilgili çok sayıda çalışmanın var olduğu görülmektedir (Alisinanoğlu, Bay ve Şimşek, 2014; Atakan, 2010; Baum ve McMurray-Schwarz, 2004; Bayraktar, Güven \& Temel, 2016; Coutts, Sheridan, Kwon, \& Semke, 2012; Çamlıbel-Çakmak, 2010; Jeynes, 2011; Koçyiğit, 2015; Kurtulmuş, 2016; Miedel ve Reynolds, 1999; Tezel Şahin ve Ünver, 2005; Ünüvar, 2010; Yazıcı, Yüksel \& Güzeller, 2005). Bu araştırmalarda, okul öncesi öğretmenlerinin Okul Öncesi Eğitim Programı İle Bütünleștirilmiş Aile Destek Eğitim Programına ve yapılan aile katılımı çalışmalarına ilişkin görüsşleri (Atakan, 2010; Koçyiğit, 2015), tutumları (Bayraktar vd., 2016), etkinlik planlarında aile katılımına yer verme durumları (Kurtulmuş, 2016), kullandıkları aile katılım stratejileri (Gökyer, 2017; Krizman, 2013), hazırlanan aile katılım programlarının çocukların gelişimine veya akademik başarılarına etkisi (Ekinci- 
Vural,2006; Jeynes, 2011; Keçeli-Kaysılı, 2008), aile katılımını etkileyen faktörleri (Gürşimşek, 2010), erken müdahale programlarında aile katılım çalışmaları (Miedel ve Reynolds, 1999), aile katılım çalışmalarına yönelik öğretmen ve ailelerin görüşlerinin karşılaştırılması (Abbak, 2008; Erkan vd., 2016; Ünüvar, 2010), ailelerin beklentilerinin neler olduğu (Yazıcı vd., 2005) ve babaların katılım düzeyine (Gürşimşek, Kefi ve Girgin, 2007) ilişkin çalışmaların yapıldığı görülmektedir. Aile katılımına yönelik alan yazında yapılan çalışmalar çoğunlukla öğretmenler ve aileler çerçevesinde incelenmiştir. Ancak öğretmen adaylarının aile katılım çalışmalarına ilişkin görüşleri ve uygulamaları konusunda yapılan çalışmaların sınırlı olduğu görülmektedir (Alaçam \& Olgan, 2017; Ateş \% CevherKalburan, 2016; Baum \& McMurray-Schwarz, 2004; Lindberg, 2014; Lindberg, 2018). Hem öğretmen adaylarının hizmet öncesi dönemde bu konuya ilişsin çalışmalarının neler olduğunun ortaya konulması hem de sınırlı sayıdaki çalışmalar nedeniyle bu araştırmanın yapılması bir gereklilik olarak ortaya çıkmıştır ve literatüre katkı getirmesi beklenmektedir. Bu kapsamda yapılan çalışmanın amacı, Kütahya Dumlupınar Üniversitesi okul öncesi öğretmenliği programı 4. Sınıf öğrencilerinin öğretmenlik uygulaması dersi kapsamında MEB 2013 Okul Öncesi Eğitim Programı'na uygun olarak hazırladıkları etkinlik planlarındaki aile katılım boyutunun incelenmesidir. Araştırmanın alt amaçları, okul öncesi öğretmen adaylarının;

- Etkinlik planlarında aile katılım çalışmalarına yer verme durumlarının incelenmesi

- Hangi etkinliklerde aile katılımı çalışması planladıkları ve planlanan etkinliklerin ne tür aile katılımı çalışması olduğunun incelenmesi

- Etkinlik planlarında aile katılım çalışmalarını planlama ve uygulama sürecinde yaşanan deneyimlerin incelenmesi şeklinde belirlenmiştir.

\section{Yöntem}

Çalışma, temel nitel araştırma yöntemi kullanılarak gerçekleştirilmiştir. Temel nitel araştırma, anlama ve sürece odaklanılan amaçlı örnekleme ile gözlem, görüşme ve dokümanlar aracılığıyla verilerin toplandığı, karşılaştırmalı veri çözümlemesi yoluyla bulguların betimlenmesi, tema ve kategorileştirilerek sunulmasıdır (Merriam, 2015).

Katılımcılar Kütahya Dumlupınar Üniversitesi Eğitim Fakültesi Okul öncesi öğretmenliği 4. sınıf öğrencileri ve bu öğrencilerin öğretmenlik uygulaması dersi kapsamında hazırladıkları etkinlik planlarıdır. Katılımcılar kolay ulaşılabilir durum örneklemesi ile belirlenmiştir ve bu katılımcılar arasından rastgele seçilen ve gönüllü olan 8 öğrenci ile görüşmeler yapılmıştır. Bu kapsamda 42 okul öncesi öğretmenliği 4. sınıf öğrencisinin etkinlik planları incelemeye alınmıştır. Öğrenciler 2018-19 bahar döneminde 12 hafta ve haftada 1 gün öğretmenlik uygulaması dersi kapsamında uygulamalar yapmışlardır. 42 öğretmen adayından 16'sı her hafta ikişer etkinlik, 26'sı ise her hafta birer etkinlik planlayarak, dönem boyunca toplam 696 etkinlik planlamışlardır. Ancak veri toplama sırasında 28 etkinlik dosyalarda bulunamadığı için eksik veri olarak değerlendirilerek 668 adet etkinlik planı çalışmaya dâhil edilmiştir.

Veri toplama araçları olarak;

- 1. ve 2. alt amaç için etkinlik planı dokümanları (Okul Öncesi Öğretmen Adayları için Aile Katılımı Etkinlik Değerlendirme Listesi ile (OÖÖAAKED)

- 3. alt amaç için yarı yapılandırılmış görüşme formu kullanılmıştır.

Okul öncesi öğretmen adayları için aile katılımı etkinlik değerlendirme listesi ve yarı yapılandırılmış görüşme formunun geliştirilmesinde araştırmacılar tarafından literatür incelenerek, belirlenen amaçlar doğrultusunda veriyi en iyi şekilde toplamaya, organize etmeye ve analiz etmeye imkan verecek başlıklar ve sorular oluşturulmuştur. Oluşturulan değerlendirme listesi ve yarı yapılandırılmış görüşme formu 3 alan uzmanı ile 1 ölçme değerlendirme uzmanına gönderilmiş ve verilen dönütler doğrultusunda son halini almıştır. Okul öncesi öğretmen adayları için aile katılımı etkinlik değerlendirme listesinde öğrencinin adı, uygulama tarihi, etkinlik numarası, etkinlik türü, aile katılımına yer verip vermeme durumu, hangi tür aile katılımı yaptığı şeklinde başlıklar yer almaktadır. Yar1 yapılandırılmış görüşme formunda ise öğretmen adaylarının, etkinlik planlarında aile katılım çalışmalarını planlama ve uygulama sürecinde yaşanan deneyimlerini ortaya koymalarını sağlayan 4 adet soru yer almaktadır. 
Veri toplama sürecinde, öğretmen adaylarına araştırmanın amacı ve içeriği açıklanarak etkinlik planlarını incelemek ve görüşme yapmak için izin istenmiş ve gönüllü katılım formu öğretmen adayları tarafından imzalanmıştır. Öğretmen adaylarının etkinlik planları araştırmacılar tarafından geliştirilen Okul Öncesi Öğretmen Adayları için Aile Katılımı Etkinlik Değerlendirme Listesi (OÖÖAAKED) ile incelenmiştir. Analizlere göre aile katılımı çalışmalarına yer veren ve vermeyen öğretmen adaylarından gönüllü olan ve rastgele seçilen 8 kişi ile araştırmacı tarafından planlanan gün ve saatte görüşmeler yapılmıştır. Görüşmeler esnasında ses kaydı alınacağı öğretmen adaylarına belirtilerek gerekli onaylar alınmıştır. 8 öğretmen adayıyla birer kez görüşme yapılmıştır. Görüşmeler 12 dakika ile 20 dakika arasında sürmüştür.

Araştırmanın verilerinin çözümlenmesinde tematik analiz (Braun ve Clarke, 2006) kullanılmıştır. Gibson ve Brown (2009), tematik analizi "verilerin ilişkiler, farklılık ve benzerlik durumları göz önüne alınarak analiz edilmesi" olarak tanımlamaktadırlar. Tematik analizde, veri içerisindeki temalar ortaya çıkarılarak, oluşan yapı ve betimlemelerin tematik ağlar ile ortaya konması amaçlanır (Attride-Stirling, 2001). Tematik analiz süreci 6 adımdan oluşmaktadır (Braun \& Clarke, 2006; Saldana, 2009):

- Verilerin tanınması için, verileri analize hazırlama ve okuma

- Tüm veri seti üzerinde durularak ilk kodların verilmesi

- Birbiriyle ilişkili bulunan kodların toplanarak kategorilerin oluşturulması

- Oluşturulan kategorilerin tekrar incelenmesi

- İncelenen kategoriler üzerinde çalışılarak temaların oluşturulması ve isimlendirilmesi

- Örnekler verilerek bulguların yazılması

Nitel araştırmalarda inanırlığın sağlanması kapsamında araştırmacılar tarafından gerçekleştirilmesi beklenen farklı stratejiler mevcuttur. Bu stratejiler; uzun süreli katılım ve sürekli gözlem, zengin betimleme, veri çeşitlemesi, olumsuz durum analizi, akran incelemesi, dış denetim, araştırmacının önyargılarının açıklanması ve üye kontrolünde olması olarak sıralanabilir (Creswell ve Miller, 2000). Creswell ve Miller (2000), araştırmanın inanırlı̆̆ının sağlanmasında bu stratejilerden en az ikisinin yerine getirilmesi gerektiğini belirtmişlerdir. Ayrıca yapılan gözlem ve görüşmelerin video veya ses kaydına alınması, ses kayıtlarının transkripsiyonlarının yapılarak, katılımcıların duraksamaları ve ünlemleri de dâhil olmak üzere tüm ifadelerin transkripsiyonda belirtilmesi, kodlama sırasında en az iki kodlayıcının olması ve kodlamalarda görüş birliğine varılması da nitel araştırmalarda inanırlığın sağlanmasında oldukça önemli kriterlerdir (Silverman, 2005). Bu kapsamda araştırmanın inanırlığının artırılması için veri toplama aracı geliştirilirken uzman görüşleri doğrultusunda gerekli düzenlemeler yapılmıştır. Görüşme sürecinde katılımcıların onayları doğrultusunda ses kaydı alınarak, ses kayıtları katılımcıların tüm ifadeleri dâhil edilerek yazıya dökülmüştür. Araştırmacılar etkinlikleri ve görüşme formlarını ayrı ayrı kodlayarak sonrasında karşılaştırmışlardır. Yapılan karşılaştırma sonucunda görüş birliği olan maddeler aynen korunmuştur, görüş ayrılığı olan maddeler ise tekrar incelenerek görüş birliğine varılmıştır. Veriler, doğrudan alıntılar ile sunularak yorumlar sonrasında verilmiştir. Ayrıca araştırmada kullanılan veri toplama araçları, ses kayıtları, ham veriler ve notlar araştırmacılar tarafından gerekmesi halinde sunulabilmesi için saklanmıştır.

\section{Bulgular}

Kütahya Dumlupınar Üniversitesi okul öncesi öğretmenliği programı 4. Sınıf öğrencilerinin, öğretmenlik uygulaması dersi kapsamında MEB 2013 Okul Öncesi Eğitim Programı'na uygun olarak hazırladıkları etkinlik planlarındaki aile katılım boyutunun incelenmesinin amaçlandığı araştırmadayapılan analizler sonucunda, öğretmen adaylarının "aile katılımına yer verme durumu" temasında öğrenciler iki gruba ayrılmıştır. Aşağıdaki şekilde ifade edildiği gibi toplam 42 öğretmen adayının 28'inin uygulama dönemi boyunca hiç aile katılım çalışması planlamamıştır. Buna karşılık 14 öğretmen adayının ise dönem boyunca aile katılım çalışmalarına etkinlik planlarında yer verdiği görülmektedir. 42 öğretmen adayının incelenen 668 etkinlik planının 286 tanesinde aile katılım çalışması yer alırken 382 tanesinde aile katılımın çalışmasının yer almadığı belirlenmiştir 


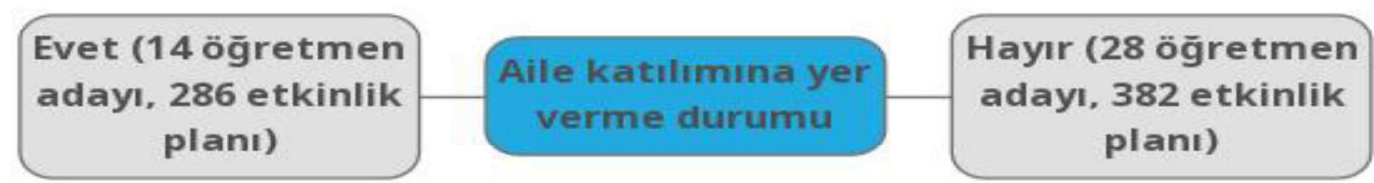

Şekil 1. Öğretmen adaylarının etkinlik planlarında aile katılımına yer verme durumları

Etkinlik planlarında aile katılım çalışmalarına yer vermeyen 4 öğretmen adayıyla yapılan görüşmelerin analizi sonucu "aile katılımına yer vermeme sebepleri" ikinci tema olarak ortaya çıkmıştır.

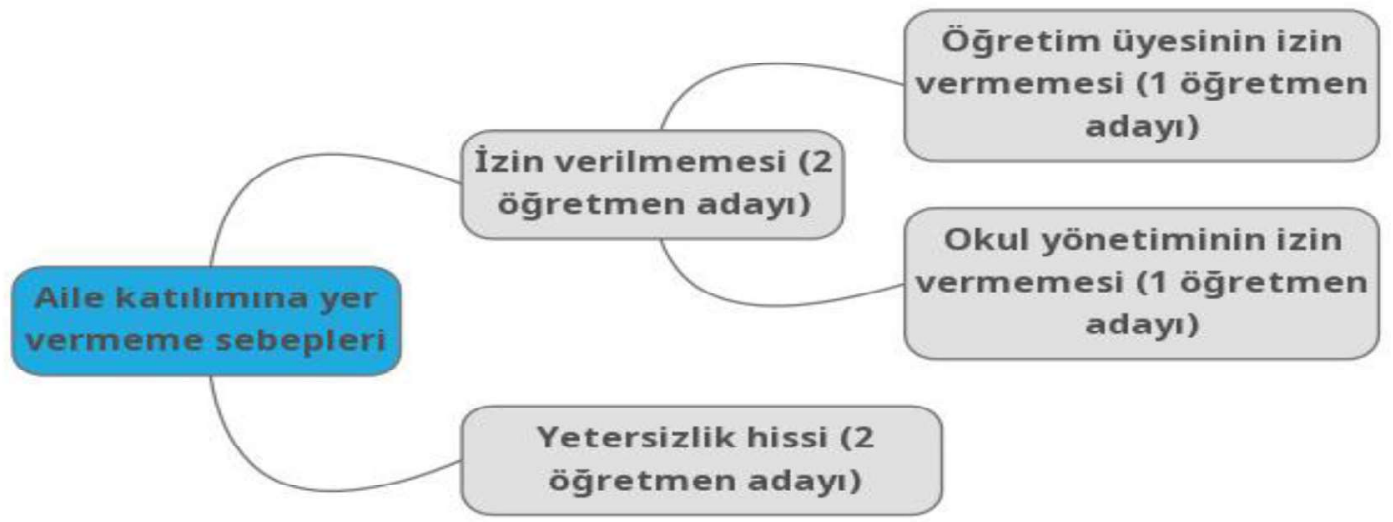

Şekil 2. Öğretmen Adaylarının Etkinli Planlarında Aile Katılımına Yer Vermeme Sebepleri

$\mathrm{Bu}$ öğretmen adaylarıyla yapılan görüşme sonuçlarına göre "yetersizlik hissi" ve "izin verilmemesi" olarak iki kategori oluşmuştur. Yetersizlik hissi kategorisinde 2 öğretmen adayı aile katılımı çalışmaları hakkında bilgilerinin olduğunu ancak bu bilginin yeterli olmadığını, uygulama yapacak veya etkinlik tasarlayacak düzeyde olmadığını belirtmişlerdir. İzin verilmemesi kategorisinde ise 2 öğretmen adayının 1 tanesi fakültedeki öğretim üyesinin aile katılım çalışmalarına yönelik hazırlık istememesi ve diğer 1 tanesi okul yönetiminin öğretmen adaylarının aileler ile herhangi bir şekilde iletişim kurmalarına izin vermemesi yönünde görüşlerini belirtmişlerdir. Bu bulguya ilişkin katılımcıların görüşleri şu şekildedir;

K3: “...yani derste aldık ama ne bileyim kendimiz yeterli hissetmiyorum, çok girmek istemiyorum ona..."

K2: “...okul müdürü çocukların aileleriyle konuşmamıza dahi izin vermiyor ki, karşılama ve uğurlamada bile konuşmuyoruz annelerle ögretmenleri konuşuyor, bize abla diyorlar zaten öğretmen gibi bile görmüyorlar..."

K1: “... hocamı her hafta iki etkinlik planlamamızı istedi, aile katılımını istemedi o yüzden hiç yapmadım..."

Aile katılım çalışmalarına etkinlik planlarında yer veren 14 öğretmen adayının 286 etkinlik planında bu çalışmaları "Hangi etkinlikler için?" planladıkları temasında, en çoktan en aza sırasıyla; 


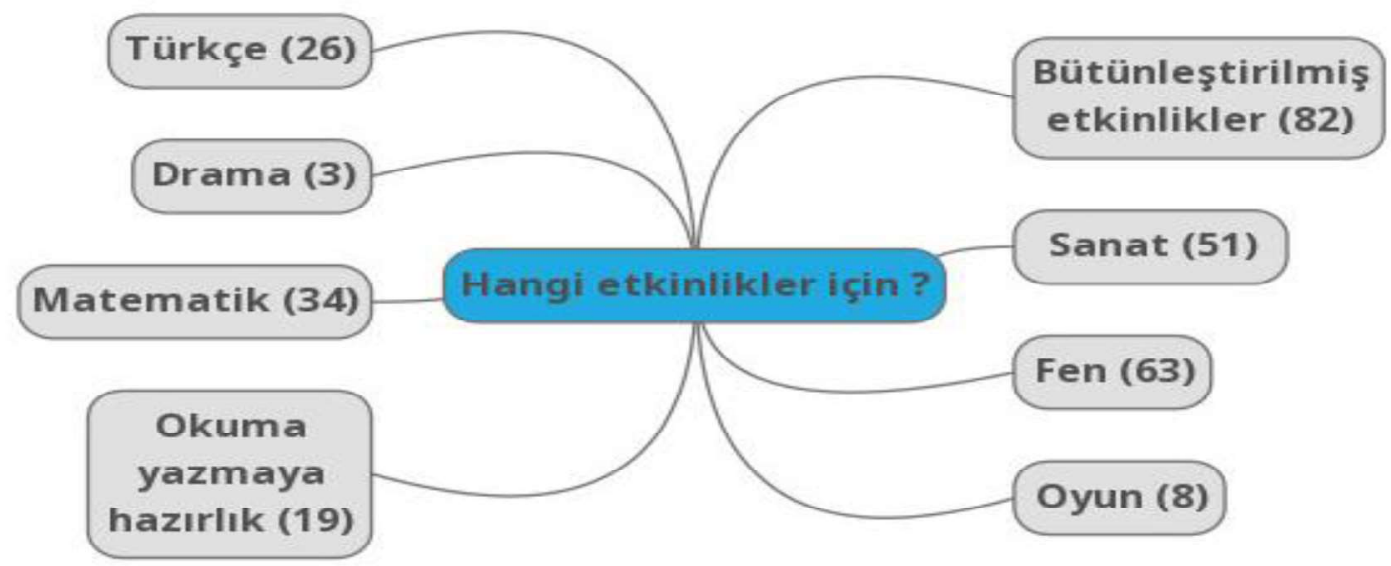

Şekil 3. Öğretmen Adaylarının Hangi Etkinlikler İçin Aile Katılımı Çalışmaları Planladıkları

Bütünleştirilmiş etkinlikler, Fen, Sanat, Matematik, Türkçe, Okuma yazmaya hazırlık, Oyun ve Drama etkinlikleri yer almıștır.

Öğretmen adaylarının etkinlik planlarındaki aile katılım çalışmalarının "Hangi tür aile katılım çalışmaları?" olduğuna yönelik belirlenen temada, 14 öğretmen adayının 286 etkinlik planında en çoktan en aza sırasıyla; hedeflenen kazanım/kavramın pekiştirilmesine yönelik etkinlik önerisi, Somut ürün oluşturup okula gönderme, sonraki etkinliklerde kullanılmak üzere evden materyal isteme, sosyal etkinlik ve gezilere katılarak öğretmene yardımcı olma şeklinde bulgular yer almıştır.

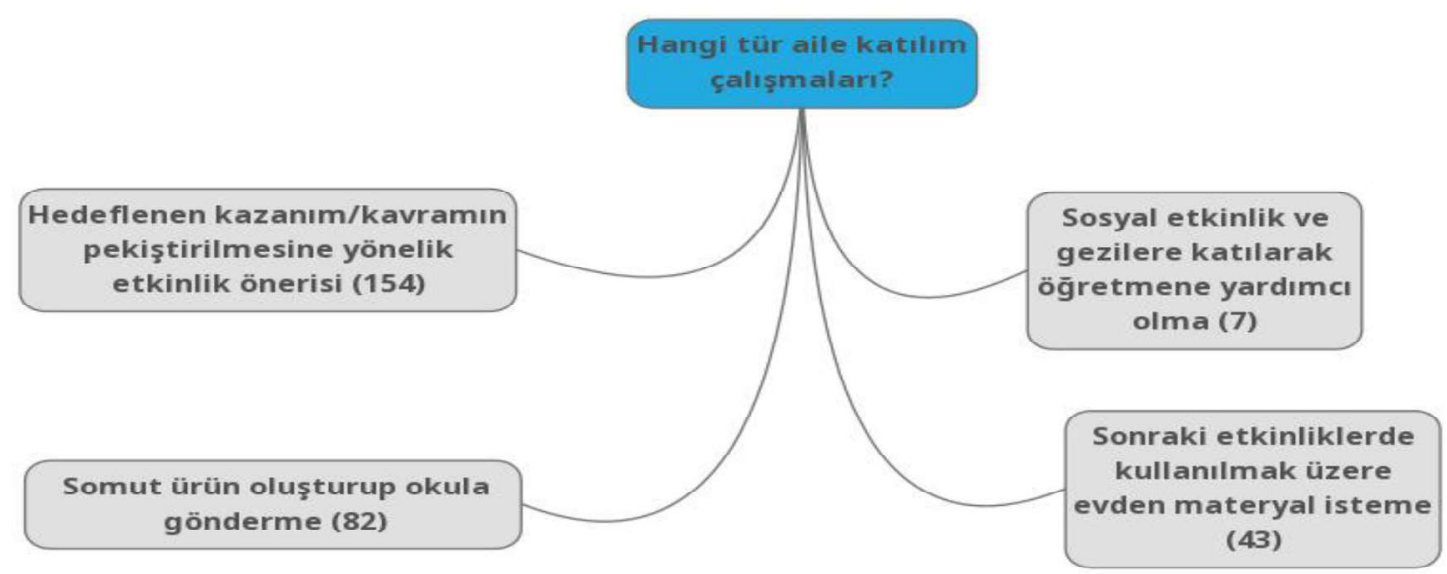

Şekil 4. Öğretmen Adaylarının Etkinliklerinde Hangi Tür Aile Katılımı Çalışmaları Planladıkları

Bu bulguya ilişkin etkinlik örnekleri planlarda şu şekilde yer almıştır:

K8: "Hayat bulan canlılar" isimli, bilişsel gelişim K.1, dil gelişimi K.7, K.8 ve göstergelerine ilişkin gerçekleştirilen Türkçe etkinliğinden sonra verilen aile katılımı çalışması: "Çocuk ailesi ile birlikte hayvanat bahçesine gidip hayvanlart inceleyebilir ve merak ettiklerini ailesine sorabilir."

K13: "Tohumum sabırla beklememi istiyor" isimli bilişsel gelişim K.1, K.5 ile sosyal duygusal gelişim K.10 ve göstergelerine ilişkin gerçekleştirilen bütünleştirilmiş etkinlikten sonra verilen aile katılım çalışması: "Biz bugün tohumları inceledik ve tohum ektik, sizde evinizde çocuğunuzun okulda gördüğ̈̈ tohumlar hakkında sohbet edebilir birlikte tohum alarak ekip büyümesini birlikte gözlemleyebilirsiniz."

K9: “Ipek yolu-baharat yolu projemiz için 13 Mayls 2019'a kadar evinizde varsa farklı baharat ve kumaşlardan göndermenizi rica ederim." 
K6: “4 Nisan 2019'da yapacağımı 'Hayvanların müzikli dünyası' drama etkinliği için çocuklarınızla birlikte canlandırmada giyebilmeleri için yaratıcı hayvan kostümü tasarlayıp 4 nisan günü okula göndermenizi rica ederim."

K13:"8 Mart 2019,10:00'da pizza yapımı için Sera Kütahya-Sbarro'ya yapılacak olan gezimize katılımınızı bekliyoruz."

Bir diğer tema olan "uygulamada yaşanan sorunlar" da, 4 öğretmen adayının etkinlik planlarında aile katılımı çalışmalarına yer verdikleri ancak süreç ve uygulama bakımından yaşadıkları zorlukları değerlendirdikleri görülmektedir.

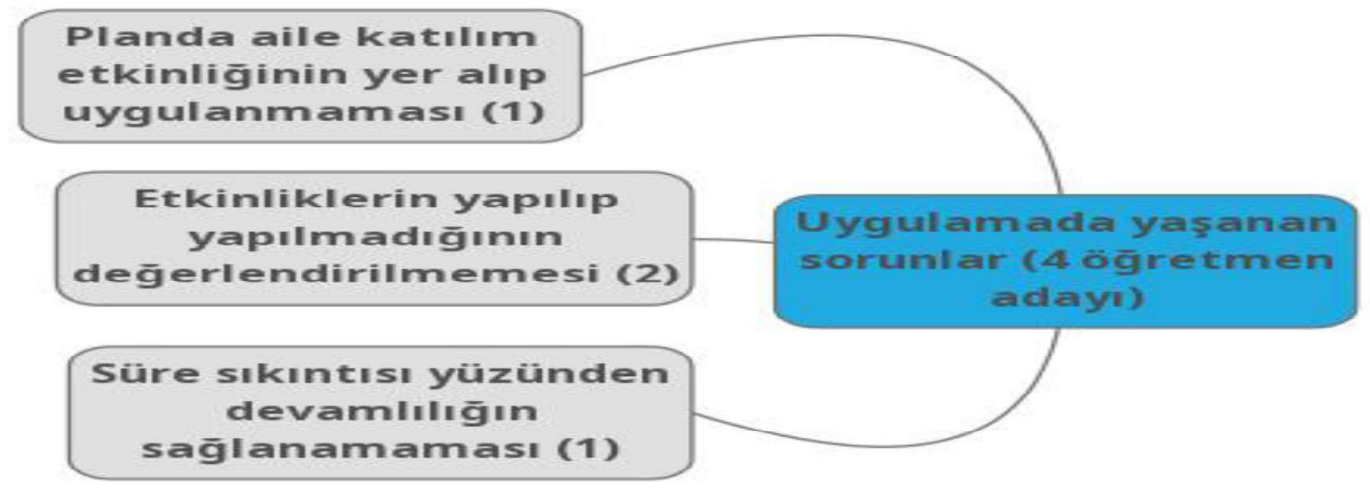

Şekil 5. Öğretmen Adaylarının Aile Katııımı Çalışmalarına İlişkin Yaşanan Sorunlar

$\mathrm{Bu}$ temada öğretmen adaylarının etkinlik planlarında aile katılımına yer verdikleri ancak görüşmeler sonucunda 2 öğretmen adayının çalışmaların aileler tarafından yapılıp yapılmadığına dair geri bildirim almadıkları, 1 öğretmen adayının çalışmaları planlayıp uygulamaya geçirmediği ve 1 öğretmen adayının haftada bir gün öğretmenlik uygulaması yaptıkları için takip ve uygulamalar konusunda süre yetersizliği olduğuna dair görüşlerini belirtmişlerdir. Bu bulguya ilişkin katılımcıların görüşleri ise şu şekildedir:

K8: “... yani yazlyorum ama planlar ailelere verilmiyor herhalde...o nastl oluyor tam hatırlamiyorum...”

K13: "... uyguluyorlar mı bilmiyorum, onunla ilgili konuşmadık hiç..."

K6: “ ...öğretmenimize danışarak aile katılımı yazıyoruz ama hocam zaten haftada bir gün gidiyoruz kopukluk oluyor, verimli değil pek..."

Bununla birlikte görüşme yapılan tüm katılımcılar okul öncesi eğitimde aile katılımının gerekliliğini ve bu konuda eğitim almak istediklerini belirtmişlerdir. Bu bulguya ilişkin katılımcıların görüşleri şu şekildedir:

K2: “...çok önemli ama hiç yapmadiğım için ... aslında öğretmen olunca ĕgitim almak isterim ve zaten de aile katılımı yaparım o zaman..."

K3: “... tabi her etkinliği yapmak lazım ve kendini daha çok geliştirmek...”

K13: “... aile katılımııı önemli yani köye atanınca aileyi bilgilendirmek, anlatmak okulda ne oluyor bildirmek lazım... çocuklarına faydası olması için şunu yapın, bunu yapın diye öneri vermekte çünkü aileler bilgisiz oluyor bizden öğrenebilirler... daha çok kongreye katılmak ve hocalardan seminer almak gerekiyor..."

\section{Tartışma, Sonuç ve Öneriler}

Aileler, çocuklarının okul öncesi eğitime başlamasıyla birlikte aile katılımı ve iş birliğine yönelik ilk tecrübelerini edinmektedirler. Dolayısıyla ailelerin okulla tanışmasını, doğru ilişkilerin ve işbirliğinin kurulmasını sağlayacak ve çocuğunun eğitim hayatını etkileyecek olan okul öncesi 
öğretmenlerinin aile katılımına yönelik, yeterlilik ve tutumları oldukça önemlidir (Biber, 2018). Erken çocukluk eğitimiyle ilgili yapılan araştırmalarda ailelerin çocukların eğitimine aktif katılımlarının, çocukların gelişim alanlarını olumlu yönde etkilediği, çocukların okula hazırlanmasında da etkili olduğu belirtilmektedir (Arabacı \& Aksoy, 2005; Günay Bilaloğlu, 2014). Öğretmen Yetiştirme ve Eğitimi Genel Müdürlüğü'nün (OYEGM), belirlemiş olduğu, öğretmenlik mesleğinin altı genel yeterliklerinden biri; okul, aile ve toplum ilişkileridir. Bu yeterlilik alanı, öğretmenlerin; çevreyi tanıma, çevre olanaklarından yararlanma, okulu kültür merkezi durumuna getirme, aileyi tanıma ve ailelerle tarafsız olarak iletişim, aile katılımı ve işbirliği sağlama konularında yeterliğe sahip olmalarını kapsamaktadır. Araştırma sonucunda katılımcıların yarıdan fazlasının etkinlik planlarında aile katılımı çalışmalarına hiç yer vermediği görülmüştür. Katılımcılar bir önceki dönem aile katılımına ilişkin ders almalarına rağmen bu bilgileri öğretmenlik uygulaması dersinde uygulamaya geçiremedikleri söylenebilir. Flanigan (2007), öğretmen adaylarının ailelere yönelik olumsuz tutumlarını önlemek ve aile katılımı ile işbirliği hakkında onların becerilerini geliştirmek amacıyla öğretmen adaylarına programa ek olarak destek eğitimi vermiştir.

Ülkemizde 2013 yılında yenilenen MEB Okul öncesi eğitim programında aile katılımı ve aile katılımı etkinliklerinin önemi vurgulanmaktadır. Okul Öncesi Eğitim Programı ile Bütünleştirilmiş Aile Destek Eğitim Rehberinde (OBADER) aile katılımı çalışmaları şu şekilde ifade edilmektedir;

1- Aile İletişim Etkinlikleri

2- Ailelerin eğitim etkinliklerine katılımı

3- Bireysel Görüşmeler ve Ev Ziyaretleri (MEB,2013).

Araştırma sonuçlarına bakıldığında katılımcıların ailelerin eğitim etkinliklerine katılımı yönünde çalışmalar yaptıkları görülmektedir. Abbak (2008) çok az uygulanan ya da hiç uygulanmayan aile katılım etkinlikleri olarak; ev ziyaretlerini, eğitim panolarını, telefon görüşmelerini, teyp kayıtlarını, toplu dosyaları ve toplantıları olarak belirtirken, Işık (2007) ise telefon görüşmelerini, seminerleri, konferansları, ev ziyaretlerini, dilek-şikâyet kutusu ve ailelerle tanışmakaynaşma toplantılarını belirtmektedir. Bu araştırmada da benzer şekilde katılımcıların aile iletişim etkinlikleri ile bireysel görüşmeler ve ev ziyaretlerine etkinlik planlarında yer vermedikleri görülmüştür. Bu durumun sebebinin katılımcıların öğretmenlik uygulaması dersi kapsamında gittikleri okulların yönetimlerinin tutum ve davranışlarından kaynaklanmış olabileceği düşünebilir.

Kurtulmuş (2016), okul öncesi öğretmenlerinin etkinlik planlarındaki aile katılımı çalışmalarını incelediği araştırmasında, öğretmenlerin en fazla matematik etkinlikleri için aile katılımı planladıklarını, sanat ile oyun ve hareket etkinlikleri için aile katılımı çalışmalarını düşük düzeyde planladıklarını ortaya koymuştur. Bu araştırmada ise katılımcılar sanat etkinliği için aile katılımı çalışmalarını üçüncü sırada planlarken oyun ve hareket etkinlikleri benzer şekilde son sıralarda yer almıştır.

$\mathrm{Bu}$ araştırma, Kütahya Dumlupınar Üniversitesi Okul öncesi öğretmenliği programı öğretmen adaylarından toplanan verilerle sınırlıdır. Araştırma farklı üniversitelerin okul öncesi öğretmen adayları ile yapılabilir. Okul yöneticileri, öğretmenlik uygulaması kapsamında öğretmen adaylarının aile katılım çalışması yapmaları konusunda teşvik edilmelidir. Öğretmen adaylarının aile katılımı etkinliklerinin içeriği ile niteliklerinin geliştirilmesi konusunda bilgilendirilmeleri ve uygulamalar yapmaları sağlanmalıdır. 


\section{Kaynakça}

Abbak, B.S. (2008). Okul öncesi eğitim programındaki aile katılımı etkinliklerinin anasınıfı ögretmenleri ve veli görüşleri açısından incelenmesi (Yayımlanmamış yüksek lisans tezi).Adana: Çukurova Üniversitesi.

Alaçam, N., ve Olgan, R. (2017). Pre-service early childhood teachers' self-efficacy beliefs towards parent involvement. Teaching Education, 28(4), 421-434.

Alisinanoğlu, F., Bay, D.N \& Şimşek, Ö. (2014). Okul öncesi eğitimde okul aile işbirliği ölçeğinin geçerlik ve güvenirlik çalışması. Ahi Evran Üniversitesi Kırşehir Eğitim Fakültesi Dergisi (KEFAD), 15(1), 1-13.

Arabacı, N. (2018). Aile katılımı. A.B. Aksoy (Ed.),Aile eğitimi ve katılımı içinde (s.126-144). Ankara: Hedef Yayıncılık.

Arabacı, N., ve Aksoy, B. A. (2005). Okul öncesi eğitime katılım programının annelerin bilgi düzeylerine etkisi. Hacettepe Üniversitesi Eğitim FakültesiDergisi, 29(29),18-26.

Atakan, H. (2010). Okul öncesi ĕgitiminde aile katılımı çalışmalarının öğretmen ve ebeveyn görüşlerine göre değerlendirilmesi (Yayımlanmamış yüksek lisans tezi). Çanakkale: Çanakkale Onsekiz Mart Üniversitesi.

Ateş, Ö., ve Cevher-Kalburan, N. (2016). Okul öncesi öğretmen adaylarının aile katılım çalışmalarına yönelik öz-yeterlik inançlarının incelenmesi. Akademik Bakış Uluslararası Hakemli Sosyal Bilimler E-Dergisi, 55, 62-88.

Attride-Stirling, J. (2001). Thematic networks: An analytic tool for qualitative research. Qualitative Research, 1 (3), 385-405.

Baum, A. C., ve McMurray-Schwarz, P. (2004). Preservice teachers' beliefs about family involvement: Implications for teacher education. Early Childhood Education Journal, 32, 5761.

Bayraktar, V., Güven, G. \& Temel, Z. F. (2016). Okul öncesi kurumlarda görev yapan öğretmenlerin aile katılım çalışmalarına yönelik tutumlarının incelenmesi. Kastamonu Ĕgitim Dergisi, 24 (2), 755-770.

Berns, R. M. (2012). Child, family, school, community: Socialization and support. Nelson Education.

Biber, K. (2018). Öğretmen adaylarının aile katılımına ilişkin öz yeterlilik inanç düzeylerinin belirlemesi. Türkiye Sosyal Araştırmalar Dergisi, 22(2), 623-642.

Braun V. ve Clarke, V. (2006). Using thematic analysis in psychology. Qualitative Research in Psychology, 3 (2), 77-101.

Christenson, S. (2004). The family-school partnership: an opportunity to promote the learning competence of all students. School Psychology Review, 33 (1), 83-104.

Coutts, M. J., Sheridan, S. M., Kwon, K., \& Semke, C. A. (2012). The effect of teacher's invitations to parental involvement on children's externalizing problem behaviors: An examination of a CBC intervention (CYFS Working Paper No. 2012-3). Retrieved from the Nebraska Center for Research on Children, Youth, Families and Schools website: cyfs.unl.edu

Cömert, D., ve Güleç, H. (2004). Okulöncesi eğitim kurumlarında aile katılımının önemi: öğretmenaile-çocuk ve kurum. Afyon Kocatepe Üniversitesi Sosyal Bilimler Dergisi, 131-145.

Creswell, J. W. \& Miller, D. L. (2000). Determining validity in qualitative inquiry. Theory Into Practice, 39, 124-130.

Çağdaş, A. ve Secer, Z. (2004). Mutlu ve sağlıklı yarınlar için anne baba eğitimi. Konya: Eğitim Kitapevi.

Çamlıbel-Çakmak, Ö. (2010). Okul öncesi eğitim kurumlarında aile katılımı. Abant İzzet Baysal Üniversitesi Sosyal Bilimler Enstitüsü Dergisi, (20)1,1-17.

Ekinci-Vural, D. (2006). Okul öncesi eğitim programındaki duyuşsal ve sosyal becerilere yönelik hedeflere uygun olarak hazırlanan aile katılımlı sosyal beceri eğitimi programının çocuklarda sosyal becerilerin gelişimine etkisi (Yayımlanmamış yüksek lisans tezi). İzmir: Dokuz Eylül Üniversitesi.

Epstein L. (2002). School, Family and Community Partnership: Caring For The Children We Share. California: Corwin Pres. 
Erkan, S., Uludağ, G., \& Dereli, F. (2016). Okul öncesi öğretmenleri, okul yöneticileri ve ebeveynlerin aile katılımına ilişkin algılarının incelenmesi. Journal of Kirsehir Education Faculty, 17(1), 221-240.

Flanigan, C. B. (2007). Preparing preservice teachers to partner with parents and communities: An analysis of College of Education faculty focus groups. School Community Journal, 17(2), 89110.

Gibson, W. J. \& Brown, A. (2009). Working with qualitative data. Los Angelos: Sage.

Gökyer, N. (2017). Okulöncesi Öğretmenlerinin Uyguladıkları Aile Katılım Stratejileri. İnönü Üniversitesi Ĕ̆itim Fakültesi Dergisi, 18(3), 334-348.

Günay-Bilaloğlu, R. (2014). Okul öncesi eğitimde aile katılımı etkinliklerinin uygulanmasında karşılaşılan sorunlar ve aile katılımı etkinliklerinin dil-matematik becerilerinin geliştirilmesine etkisi (Yayımlanmamış doktora tezi). Adana: Çukurova Üniversitesi.

Gürşimşek, I. (2010). Okul öncesi eğitime aile katılımını etkileyen faktörler. Eğitim Bilimleri ve Uygulama, 9(18), 1-19.

Gürşimşek, I., Kefi S. \& Girgin, G. (2007). Okul öncesi eğitime babaların katılım düzeyi ile ilgili değişkenlerin incelenmesi. Hacettepe Üniversitesi Eğitim Fakültesi Dergisi,33, 181-191.

Heckman, J.J. (2011). The economics of Inequality: The Value of Early Childhood Education. American Educator,35(1),31-47.

Işık, H. (2007). Okul öncesi eğitim kurumlarında gerçekleştirilen okul-aile işbirliği çalışmalarının anne-baba görüşlerine dayalı olarak incelenmesi (Yayımlanmamış yüksek lisans tezi). Eskişehir: Anadolu Üniversitesi.

Jeynes, W. H.(2011). Parental involvement and academic success. Routledge Taylor veFrancis Group Newyork and London.

Keçeli-Kaysılı, B. (2008). Akademik başarının arttırılmasında aile katılımı. Ankara Üniversitesi Ĕgitim Bilimleri Fakültesi Özel Ĕ̈itim Dergisi, 9(01), 69-83.

Koçyiğit, S. (2015). Family involvement in preschool education: rationale, problems and solutions for the participants. Educational Sciences: Theory and Practice, 15(1), 141-157.

Krizman, C. (2013). The relationship between teachers" self-efficacy beliefs and parental involvement practices: A multi-method study (Unpublished doctoral dissertation). Texas Tech University, USA.

Kurtulmuş, Z. (2016). Okul öncesi eğitimde uygulanan etkinlik planlarında aile katilimi boyutunun incelenmesi. Cumhuriyet International Journal of Education, 5(1), 71-84.

Lindberg, E.N. (2014). Eğitim fakültesi son sınıf öğrencilerinin aile katılımı ile ilgili görüşleri. Educational Sciences: Theory ve Practice, 14(4), 1339-1361.

Lindberg, N. (2018). Parental Involvement in Teacher Education: What, Why and How?. Kastamonu Education Journal, 26(3), 965-974.

MEB, (2013). Okul Öncesi Ĕgitim Programı ile Bütünleştirilmiş Aile Destek Eğitim Programı. Ankara: T.C. Millî Eğitim Bakanlığı, Temel Eğitim Genel Müdürlüğü.

Merriam, S. B. (2015). Nitel araştırma: Desen ve uygulama için bir rehber (3. Basımdan Çeviri). (Çev. Ed. S. Turan). Ankara: Nobel Yayıncılık

Miedel, W. T. ve Reynolds, A. J.(1999). Parent involvement in early intervention for disadvantaged children: does it matter? Journal of School Psychology, 37(4), 379-402.

Saldana, J. (2009). The coding manual for qualitative researchers. Los Angelos: Sage.

Silverman, D. (2005). Doing qualitative research. Thousand Oaks, CA: Sage Publication.

Tezel Şahin, F. ve Özyürek, A. (2010). Anne baba eğitimi ve okul öncesinde aile katılımı. İstanbul, Morpa Yayınevi.

Tezel Şahin, F. ve Ünver, N. (2005). Okul öncesi eğitim programlarına aile katılımı. Kastamonu Ĕgitim Dergisi,13(1), 23-30.

Trawick-Swith, J. (2013). Erken çocukluk döneminde gelişim. (Çev. Ed. B. Akman),Çok kültürlü bir bakış açısı. Ankara: Nobel Yayıncılık.

Ünüvar, P. (2010). Aile katılımı çalışmalarına yönelik ebeveyn ve öğretmen görüşlerinin karşılaştırılması. Kastamonu Ĕgitim Dergisi, 18(3), 719-730.

Yazıcı, Z., Yüksel, B. \& Güzeller, C. (2005). Ebeveynlerin okul öncesi eğitimde uygulanan aile katılım çalışmalarından beklentileri, Mesleki Eğitim Dergisi,7(13), 63-76. 